\title{
PENINGKATAN MUTU PEMBELAJARAN MELALUI SUPERVISI AKADEMIK DI SMPN 8 LAMBU SEMESTER GANJIL TAHUN PELAJARAN 2018/2019
}

\author{
Arif Rahman \\ SMPN 8 Lambu \\ arifrahmansoro427@gmail.com
}

\begin{abstract}
ABSTRAK
Guru wajib membekali dirinya ilmu kependidikan dan usaha-usaha yang memacu peningkatan intelektual akademik dalam keselarasan mengajar terutama upaya meningkatkan gairah atau minat membaca pengetahuan kependidikan di luar rencana pelaksanaan pembelajaran di kelas secara kesadarandan kemandirian guru tersebut. Salah satu upaya untuk meningkatkan kinerja guru dan mutu pembelajaran adalah melakukan kegiatan supervisi akademik. Supervisi akademik merupakan serangkaian kegiatan membantu guru mengembangkan kemampuannya mengelola proses pembelajaran demi pencapaian tujuan pembelajaran Glickman (1981). Sementara itu, Daresh (1989) menyebutkan bahwa supervisi akademik merupakan upaya membantu guru-guru mengembangkan kemampuannya mencapai tujuan pembelajaran. Dengan demikian, esensi supervisi akademik itu sama sekali bukan menilai unjuk kerja guru dalam mengelola proses pembelajaran, melainkan membantu guru mengembangkan kemampuan profesionalismenya. Subyek dalam penelitian ini adalah guru SMPN 8 Lambu. Rancangan penelitian ini menggunakan rancangan penelitian tindakan kelas dengan dua siklus. Setiap siklus meliputi tahap perencanaan, pelaksanaan, pengamatan, dan refleksi.

Berdasarkan analisis data, disimpulkan bahwa bimbingan berkelanjutan dapat meningkatkan motivasi guru dalam menyusun administrasi mengajar dengan lengkap dan perencanaan mengajar melalui supervisi akademik sehingga menghasilkan pembelajaran yang lebih bermutu. Bimbingan berkelanjutan dapat meningkatkan motivasi guru dalam menyusun administrasi mengajar dengan lengkap dan perencanaan mengajar melalui supervisi akademik sehingga menghasilkan pembelajaran yang lebih bermutu. Guru menunjukkan keseriusan dalam memahami dan menyusun administrasi mengajar apalagi setelah mendapatkan bimbingan pengembangan administrasi mengajar/ RPP dari peneliti sehingga terjadinya peningkatan. Kegiatan supervisi akademik dapat meningkatkan kompetensi guru dalam menyiapkan perencanaan pembelajaran yang pada akhirnya meningkatkan mutu pembelajaran. Hal itu dapat dibuktikan dari hasil observasi /pengamatan yang memperlihatkan bahwa terjadi peningkatan kompetensi guru dalam mengajar dari siklus ke siklus sehingga terjadinya peningkatan dalam perencanaan pembelajaran. Telah terbukti bahwa dengan bimbingan berkelanjutan dapat meningkatkan motivasi dan kompetensi guru dalam menyusun administrasi mengajar dan perencanaan pembelajaran. Oleh karena itu, peneliti menyampaikan beberapa saran sebagai berikut. Motivasi yang sudah tertanam khususnya dalam penyusunan administrasi mengajar dan perencanaan pembelajaran hendaknya terus dipertahankan dan ditingkatkan.
\end{abstract}

Kata-Kata Kunci : Mutu Pembelajaran, Supervisi Akademik

\section{PENDAHULUAN}

Salah satu aspek penentu upaya peningkatan standar mutu bagi guru adalah wawasan intelektual guru yang menopang kompetensi mengajar. Ini merupakan syarat guru dalam melakukan inovasi diri guna meningkatkan kinerja sebagai seorang pendidik dan pengajar di kelas. Dalam hal ini penulis selaku peneliti sekaligus Pengawas Sekolah memberikan apresiasi terhadap kemajuan sekolah terutama aspek kemampuan pengetahuan guru dalam melakukan kegiatan belajar mengajar di kelas

Tujuan Pendidikan Nasional Indonesia tertuang dalam Garis-Garis Besar Haluan 2004 adalah untuk meningkatkan ketaqwaan terhadap Tuhan Yang Maha Esa, kecerdasan, 
keterampilan mengerti budi pekerti, memperkuat kepribadian dan mempertebal semangat kebangsaan agar dapat menumbuhkan manusia pembangunan yang dapat membangun dirinya sendiri bersama-sama bertanggung jawab atas pembangunan bangsa. (Lapasila IKIP Malang, $2004: 56)$.

Hal tersebut diperjelas dalam Undang-Undang Republik Indoneia Sistem Pendidikan Nasional No. 20 Tahun 2003 pasal 39 ayat 2 : Pendidikan Naisonal mencerdaskan kehidupan bangsa dan mengembangkan manusia Indonesia seutuhnya yaitu manusia yang beriman dan bertaqwa kepada Tuhan Yang Maha Esa dan berbudi luhur memiliki pengetahuan dan keterampilan, kesehatan jasmani dan rohani, rasa tanggung jawab kemasyarakatan dan kebangsaan. (Sisdiknas, 2003 :56).

Sesuai dengan tujuan pendidikan tersebut, khususnya dalam usaha menyiapkan guru dalam meningkatkan kompetensi dan etos kerja mengajar di kelas maka diperlukan motivasi dan binaan secara pisitif dan simultan serta berkelanjutan dari pengawas sekolah, hal ini diharapkan para guru memiliki kemandirian serta kemampuan akademik untuk mengajar serta mendidik para anak didiknya di lembaga pendidikan tingkat dasar yakni sekolah dasar.

Guru dituntut mampu memahami makna dan karakter kurikurikulum sehingga dapat menguasai materi, metoda, teknik, evaluasi pembelajaran sehingga hasil pembelajaran pada suatu satuan pendidikan dapat dicapai secara maksimal dan bermutu. Peraturan pemerintah No 10 tahun 2005 bab I pasal 1 ayat 6 bahwa standar proses pendidikan adalah standar nasional yang berkaitan dengan pelaksanaan pembelajaran pada satuan pendidikan untuk mencapai suatu standar kompetensi lulusan. Guru wajib membekali dirinya ilmu kependidikan dan usahausaha yang memacu peningkatan intelektual akademik dalam keselarasan mengajar terutama upaya meningkatkan gairah atau minat membaca pengetahuan kependidikan di luar rencana pelaksanaan pembelajaran di kelas secara kesadarandan kemandirian guru tersebut. Salah satu upaya untuk meningkatkan kinerja guru dan mutu pembelajaran adalah melakukan kegiatan supervisi akademik.

Supervisi akademik merupakan serangkaian kegiatan membantu guru mengembangkan kemampuannya mengelola proses pembelajaran demi pencapaian tujuan pembelajaran Glickman (1981). Sementara itu, Daresh (1989) menyebutkan bahwa supervisi akademik merupakan upaya membantu guru-guru mengembangkan kemampuannya mencapai tujuan pembelajaran. Dengan demikian, esensi supervisi akademik itu sama sekali bukan menilai unjuk kerja guru dalam mengelola proses pembelajaran, melainkan membantu guru mengembangkan kemampuan profesionalismenya 
Atas dasar pemikiran inilah yang menggugah perhatian penulis untuk melakukan penelitian dalam menyusun penelitian tindakan sekolah dengan mengangkat judul: Peningkatan Mutu Pembelajaran Melalui Supervisi Akademik di SMPN 8 Lambu Semester Ganjil Tahun Pelajaran 2018/2019.

\section{METODE PENELITIAN}

Metode yang digunakan dalam penelitian ini adalah metode Penelitian Tindakan Sekolah (PTS). Penelitian tindakan sekolah merupakan "(1) penelitian partisipatoris yang menekankan pada tindakan dan refleksi berdasarkan pertimbangan rasional dan logis untuk melakukan perbaikan terhadap suatu kondisi nyata; (2) memperdalam pemahaman terhadap tindakan yang dilakukan; dan (3) memperbaiki situasi dan kondisi sekolah / pembelajaran secara praktis" (Depdiknas, 2008 : 11-12). Secara singkat, PTS bertujuan untuk mencari pemecahan permasalahan nyata yang terjadi di sekolah-sekolah, sekaligus mencari jawaban ilmiah bagaimana masalah-masalah tersebut bisa dipecahkan melalui suatu tindakan perbaikan.

Penelitian ini adalah penelitian tindakan model Stephen Kemmis dan Mc. Taggart (1998) yang diadopsi oleh Suranto $(2000 ; 49)$ yang kemudian diadaptasikan dalam penelitian ini. Model ini menggunakan sistem spiral refleksi diri yang dimulai dari rencana, tindakan, pengamatan, refleksi, dan perencanaan kembali yang merupakan dasar untuk suatu ancangancang pemecahan masalah. Kegiatan penelitian tindakan sekolah ini, terdiri atas beberapa tahap, yaitu : perencanaan, pelaksanaan, pengamatan, dan refleksi.

Penelitian ini dilaksanakan di SMPN 8 Lambu Subyek dalam penelitian penelitian tindakan sekolah ini adalah guru-guru di SMPN 8 Lambu Tahun Pelajaran 2018/2019. Penelitian ini berbentuk Penelitian Tindakan Sekolah (School Action Research), yaitu sebuah penelitian yang merupakan kerjasama antara peneliti dan guru, dalam meningkatkan kemampuan guru agar menjadi lebih baik dalam menyusun proses pembelajaran. Metode yang digunakan dalam penelitian ini adalah metode deskriptif, dengan menggunakan teknik persentase untuk melihat peningkatan yang terjadi dari siklus ke siklus. Metode deskriptif dapat diartikan sebagai prosedur pemecahan masalah yang diselidiki dengan menggambarkan/melukiskan keadaan subjek penelitian seseorang, lembaga, masyarakat, dan lain-lain) pada saat sekarang berdasarkan fakta-fakta yang tampak atau sebagaimana adanya (Nawawi, 2005:63). Dengan metode ini peneliti berupaya menjelaskan data yang dikumpulkan melalui komunikasi langsung atau wawancara, observasi/ pengamatan, dan diskusi yang berupa persentase atau angka-angka. 
Teknik pengumpulan data dilakukan dengan dokumentasi berupa hasil karya penyusunan administrasi mengajar, wawancara dan instrument analisis penilaian. Sehubungan dengan penelitian ini maka teknik pengumpulan data yang digunakan sebagai berikut:

1. Perencanaan Tindakan
a) Pemilihan topik
b) Melakukan review silabus untuk mendapatkan kejelasan tujuan pembelajaran untuk topik tersebut dan mencari ide-ide dari materi yang ada dalam buku pelajaran.
c) Menyusun rencana pelaksanaan pembelajaran
d) Menentukan indikator yang akan dijadikan acuan
e) Mempersiapkan kelompok mata pelajaran
f) Mempersiapkan media pembelajaran.
g) Membuat format evaluasi
h) Membuat format observasi
i) Membuat angket respon guru dan siswa

2. Pelaksanaan Tindakan

Menerapkan tindakan sesuai dengan rencana, dengan langkah-langkah:

a) Setiap guru yang telah menyusun rencana pembelajaran menyajikan atau mempresentasikan rencana pembelajarannya, sementara rekan/guru lain memberi masukan, sampai akhirnya diperoleh rencana pembelajaran yang lebih baik.

b) Guru yang ditunjuk menggunakan masukan-masukan tersebut untuk memperbaiki rencana pembelajaran.

c) Guru yang ditunjuk tersebut mempresentasikan rencana pembelajarannya di depan kelas untuk mendapatkan umpan balik.

3. Pengamatan (observasi)

a) Observer melakukan pengamatan sesuai rencana dengan menggunakan lembar observasi.

b) Menilai tindakan dengan menggunakan format evaluasi.

c) Pada tahap ini seorang guru melakukan implementasi rencana pembelajaran yang telah disusun, guru lain melakukan observasi dengan menggunakan lembar observasi yang telah dipersiapkan.

Teknik analisis Data menggunakan analisis deskriptif persentase, yakni membandingkan persentase jumlah guru yang membuat administrasi mengajar dan perencanaan pembelajaran, seperti : (1) Peningkatan pembuatan administrasi mengajar yang dilakukan oleh guru minimal $75 \%$, (2) Peningkatan perencanaan pembelajaran melalui supervisi akademik yang dilakukan 
oleh guru minimal 80\%, (3) Pembelajaran yang bermutu yang ditandai dengan tingkat keaktifan siswa dalam belajar di atas $75 \%$.

\section{HASIL DAN PEMBAHASAN}

Dari hasil wawancara terhadap sepuluh orang guru, peneliti memperoleh informasi bahwa semua guru (sepuluh orang) belum tahu kerangka penyusunan administrasi mengajar seperti RPP dengan menerapkan model-model pembelajaran, hanya tiga orang yang memiliki dokumen standar proses (satu buah), hanya empat orang guru yang pernah mengikuti pelatihan pengembangan RPP dengan penerapan model-model pembelajaran, umumnya guru mengadopsi dan mengadaptasi RPP yang menerapkan model-model pembelajaran didalamnya, kebanyakan guru tidak tahu dan tidak paham menyusun RPP dengan penerapan model-model pembelajaran secara lengkap, mereka setuju bahwa guru harus menggunakan RPP dengan menerapkan model-model pembelajaran dalam melaksanakan proses pembelajaran yang dapat dijadikan pedoman dalam proses pembelajaran. Selain itu, kebanyakan guru belum tahu dengan komponen-komponen RPP yang menerapkan model-model pembelajaran secara lengkap.

Berdasarkan hasil observasi peneliti terhadap sepuluh RPP yang dibuat guru (khusus pada siklus 1), diperoleh data bahwa masih ada guru yang tidak melengkapi RPP-nya dengan komponen dan sub-subkomponen RPP penerapan model pembelajaran tertentu, misalnya komponen indikator dan penilaian hasil belajar (pedoman penskoran dan kunci jawaban). Rumusan kegiatan siswa pada komponen langkah-langkah kegiatan pembelajaran masih kurang interaktif, inspiratif, dan sistematis.

1. Hasil Penelitian Siklus I

Siklus pertama terdiri dari empat tahap yakni: (1) perencanaan, (2) pelaksanaan, (3) pengamatan, dan (4) refleksi seperti berikut ini. Pada awal siklus pertama administrasi mengajar yang dibuat para guru belum sesuai seperti keinginan peneliti. Hal itu dibuktikan dengan masih adanya komponen administrasi mengajar seperti 1) silabus, 2) RPP, 3) Prota, 4) Promes, 5) Daftar hadir (DH), dan 6) Daftar Nilai (DN) belum dibuat oleh guru. Kondisi awal guru SMPN 8 Lambu yang membuat administrasi mengajar .

Tabel 1

Kondisi awal guru SMPN 8 Lambu yang membuat Administrasi mengajar

\begin{tabular}{|c|l|c|c|c|c|c|c|}
\hline No & Nama & Silabus & RPP & Prota & Prosem & DH & DN \\
\hline 1 & Guru SMPN 8 Lambu & $\checkmark$ & $\checkmark$ & $\checkmark$ & $\checkmark$ & $\checkmark$ & $\checkmark$ \\
\hline 2 & Guru SMPN 8 Lambu & $\checkmark$ & $\checkmark$ & $\checkmark$ & $\checkmark$ & & $\checkmark$ \\
\hline 3 & Guru SMPN 8 Lambu & $\checkmark$ & $\checkmark$ & $\checkmark$ & $\checkmark$ & $\checkmark$ & $\checkmark$ \\
\hline 4 & Guru SMPN 8 Lambu & $\checkmark$ & $\checkmark$ & & $\checkmark$ & $\checkmark$ & $\checkmark$ \\
\hline
\end{tabular}




\begin{tabular}{|c|l|c|c|c|c|c|c|}
\hline 5 & Guru SMPN 8 Lambu & $\checkmark$ & $\checkmark$ & $\checkmark$ & & $\checkmark$ & $\checkmark$ \\
\hline 6 & Guru SMPN 8 Lambu & $\checkmark$ & $\checkmark$ & $\checkmark$ & $\checkmark$ & $\checkmark$ & \\
\hline 7 & Guru SMPN 8 Lambu & $\checkmark$ & & $\checkmark$ & $\checkmark$ & $\checkmark$ & $\checkmark$ \\
\hline 8 & Guru SMPN 8 Lambu & $\checkmark$ & $\checkmark$ & $\checkmark$ & $\checkmark$ & $\checkmark$ & \\
\hline 9 & Guru SMPN 8 Lambu & $\checkmark$ & $\checkmark$ & $\checkmark$ & & $\checkmark$ & $\checkmark$ \\
\hline 10 & Guru SMPN 8 Lambu & $\checkmark$ & & $\checkmark$ & $\checkmark$ & $\checkmark$ & \\
\hline 11 & Guru SMPN 8 Lambu & $\checkmark$ & & $\checkmark$ & $\checkmark$ & & $\checkmark$ \\
\hline 12 & Guru SMPN 8 Lambu & $\checkmark$ & $\checkmark$ & & $\checkmark$ & $\checkmark$ & $\checkmark$ \\
\hline
\end{tabular}

Tabel 2

Format Tindak Lanjut Hasil Supervisi Akademis

\begin{tabular}{|c|l|c|c|}
\hline No & \multicolumn{1}{|c|}{ Nama Guru } & $\begin{array}{c}\text { Rencana Tindak } \\
\text { Lanjut }\end{array}$ & $\begin{array}{c}\text { Hasil yang } \\
\text { diharapkan }\end{array}$ \\
\hline 1 & Guru SMPN 8 Lambu & Dialog kolaboratif & Lebih Baik \\
\hline 2 & Guru SMPN 8 Lambu & Dialog kolaboratif & Lebih baik \\
\hline 3 & Guru SMPN 8 Lambu & Dialog kolaboratif & Lebih baik \\
\hline 4 & Guru SMPN 8 Lambu & Dialog kolaboratif & Lebih baik \\
\hline 5 & Guru SMPN 8 Lambu & Dialog kolaboratif & Lebih baik \\
\hline 6 & Guru SMPN 8 Lambu & Dialog kolaboratif & Lebih baik \\
\hline 7 & Guru SMPN 8 Lambu & Dialog kolaboratif & Lebih baik \\
\hline 8 & Guru SMPN 8 Lambu & Dialog kolaboratif & Lebih baik \\
\hline 9 & Guru SMPN 8 Lambu & Dialog kolaboratif & Lebih baik \\
\hline 10 & Guru SMPN 8 Lambu & Dialog kolaboratif & Lebih baik \\
\hline 11 & Guru SMPN 8 Lambu & Dialog kolaboratif & Lebih baik \\
\hline 12 & Guru SMPN 8 Lambu & Dialog kolaboratif & Lebih baik \\
\hline
\end{tabular}

Hasil pengamatan pada siklus 1 dapat dideskripsikan berikut ini: Pengamatan dilaksanakan terhadap 12 orang guru. Semuanya menyusun administrasi mengajar, tapi masih ada guru yang belum melengkapi administrasi mengajarnya dengan komponen administrasi mengajar seperti 1) silabus, 2) RPP, 3) Prota, 4) Promes, 5) Daftar hadir (DH), dan 6) Daftar Nilai (DN). Hasil pengamatan dari 12 guru didapatkan sebagai berikut : (1) Tiga orang tidak melengkapinya dengan RPP, (2) Dua orang tidak melengkapinya dengan prota, (3) Dua orang tidak melengkapinya dengan promes, (4) Dua orang tidak melengkapinya Daftar Hadir (DH), (5) Tiga orang tidak melengkapinya Daftar Nilai (DN)

Selanjutnya mereka dibimbing dan disarankan untuk melengkapinya dengan pendekatan dialog kolaboratif Kegiatan refleksi berupa renungan atau pertanyaan yang dapat dijadikan acuan untuk melangkah ke siklus 2, diantaranya : (1) Guru kurang melengkapi semua administrasinya dengan lengkap, (2) Belum ada sosialisasi tentang perubahan atau pengembangan administrasi mengajar.

2. Hasil Penelitian Siklus II

Melihat hasil siklus I yang kurang maksimal, maka guna memaksimalkan hasil yang diingin dicapai maka dilakukan siklus lanjutan. Siklus lanjutan ini juga terdiri dari tindakan perencanaan, pelaksanaan tindakan, observasi dan refleksi. Pada siklus ke-II administrasi 
mengajar yang dibuat para guru sudah sesuai seperti keinginan peneliti. Hal itu dibuktikan dengan masih adanya komponen administrasi mengajar seperti 1) silabus, 2) RPP, 3) Prota, 4) Promes, 5) Daftar hadir (DH), dan 6) Daftar Nilai (DN) belum dibuat oleh guru. Pengamatan dilaksanakan terhadap 12 orang guru. Semuanya menyusun administrasi mengajar, tapi masih ada guru yang belum sepenuhnya melengkapi komponenkomponen administrasi mengajar yang diperlukan, diantaranya :

Tabel 3

Kondisi Akhir Guru Yang Membuat Administrasi Mengajar

\begin{tabular}{|c|l|c|c|c|c|c|c|}
\hline No & Nama & Silabus & RPP & Prota & Prosem & DH & DN \\
\hline 1 & Guru SMPN 8 Lambu & $\checkmark$ & $\checkmark$ & $\checkmark$ & $\checkmark$ & $\checkmark$ & $\checkmark$ \\
\hline 2 & Guru SMPN 8 Lambu & $\checkmark$ & $\checkmark$ & $\checkmark$ & $\checkmark$ & $\checkmark$ & $\checkmark$ \\
\hline 3 & Guru SMPN 8 Lambu & $\checkmark$ & $\checkmark$ & $\checkmark$ & $\checkmark$ & $\checkmark$ & $\checkmark$ \\
\hline 4 & Guru SMPN 8 Lambu & $\checkmark$ & $\checkmark$ & $\checkmark$ & $\checkmark$ & $\checkmark$ & $\checkmark$ \\
\hline 5 & Guru SMPN 8 Lambu & $\checkmark$ & $\checkmark$ & $\checkmark$ & $\checkmark$ & $\checkmark$ & $\checkmark$ \\
\hline 6 & Guru SMPN 8 Lambu & $\checkmark$ & $\checkmark$ & $\checkmark$ & $\checkmark$ & $\checkmark$ & $\checkmark$ \\
\hline 7 & Guru SMPN 8 Lambu & $\checkmark$ & $\checkmark$ & $\checkmark$ & $\checkmark$ & $\checkmark$ & \\
\hline 8 & Guru SMPN 8 Lambu & $\checkmark$ & $\checkmark$ & $\checkmark$ & $\checkmark$ & $\checkmark$ & $\checkmark$ \\
\hline 9 & Guru SMPN 8 Lambu & $\checkmark$ & $\checkmark$ & $\checkmark$ & $\checkmark$ & $\checkmark$ & $\checkmark$ \\
\hline 10 & Guru SMPN 8 Lambu & $\checkmark$ & $\checkmark$ & $\checkmark$ & $\checkmark$ & $\checkmark$ & $\checkmark$ \\
\hline 11 & Guru SMPN 8 Lambu & $\checkmark$ & $\checkmark$ & $\checkmark$ & $\checkmark$ & $\checkmark$ & $\checkmark$ \\
\hline 12 & Guru SMPN 8 Lambu & $\checkmark$ & $\checkmark$ & $\checkmark$ & $\checkmark$ & $\checkmark$ & $\checkmark$ \\
\hline
\end{tabular}

Tabel 4

Format Tindak Lanjut Hasil Supervisi Akademis

\begin{tabular}{|c|l|c|c|}
\hline No & \multicolumn{1}{|c|}{ Nama Guru } & Rencana Tindak Lanjut & $\begin{array}{c}\text { Hasil yang } \\
\text { diharapkan }\end{array}$ \\
\hline 1 & Guru SMPN 8 Lambu & Dialog kolaboratif & Lebih baik \\
\hline 2 & Guru SMPN 8 Lambu & Dialog kolaboratif & Lebih baik \\
\hline 3 & Guru SMPN 8 Lambu & Dialog kolaboratif & Lebih baik \\
\hline 4 & Guru SMPN 8 Lambu & Dialog kolaboratif & Lebih baik \\
\hline 5 & Guru SMPN 8 Lambu & Dialog kolaboratif & Lebih baik \\
\hline 6 & Guru SMPN 8 Lambu & Dialog kolaboratif & Lebih baik \\
\hline 7 & Guru SMPN 8 Lambu & Dialog kolaboratif & Lebih baik \\
\hline 8 & Guru SMPN 8 Lambu & Dialog kolaboratif & Lebih baik \\
\hline 9 & Guru SMPN 8 Lambu & Dialog kolaboratif & Lebih baik \\
\hline 10 & Guru SMPN 8 Lambu & Dialog kolaboratif & Lebih baik \\
\hline 11 & Guru SMPN 8 Lambu & Dialog kolaboratif & Lebih baik \\
\hline 12 & Guru SMPN 8 Lambu & Dialog kolaboratif & Lebih baik \\
\hline
\end{tabular}

Berdasarkan tabel diatas terdapat satu orang tidak melengkapinya Daftar Nilai (DN). Selanjutnya mereka dibimbing dan disarankan untuk melengkapinya dengan pendekatan dialog kolaboratif. Berdasarkan hasil pengamatan pada siklus II baik guru maupun siswa sudah mengalami peningkatan dalam proses pembelajaran. Adapun hasil refleksinya 
sebagai berikut: (1) Guru sudah mampu melengkapi administrasi mengajar, (2) Sudah ada sosialisasi pengembangan administrasi mengajar, (3) Guru antusias dalam melengkapi administrasi mengajar.

Penelitian Tindakan Sekolah dilaksanakan di SMPN 8 Lambu terdiri atas 12 guru, dan dilaksanakan dalam siklus 1 dan siklus 2. Semua guru tersebut menunjukkan sikap yang baik dan termotivasi dalam menyusun administrasi mengajar dengan lengkap. Hal ini peneliti ketahui dari hasil pengamatan pada saat melakukan wawancara dan bimbingan penyusunan administrasi mengajar. Selanjutnya dilihat dari kompetensi guru dalam menyusun administrasi mengajar, terjadi peningkatan dari siklus 1 ke siklus 2. Adanya keseriusan para guru yang disupervisi akademik menghasilkan tidak hanya peningkatan kemampuan mengajar mereka, melainkan juga administrasi mengajar mereka lengkap sehingga dapat meningkatkan mutu pembelajaran.

Pada siklus pertama semua guru mencantumkan identitas mata pelajaran dalam RPP penerapan model-model pembelajarannya (melengkapi RPP penerapan model-model pembelajarannya dengan identitas mata pelajaran). Pada siklus II guru tersebut mencantumkan identitas mata pelajaran dalam RPP dan melengkapi administrasi mengajar lainnya.

\section{KESIMPULAN}

Berdasarkan hasil Penelitian Tindakan Sekolah (PTS) dapat disimpulkan sebagai berikut. (1) Bimbingan berkelanjutan dapat meningkatkan motivasi guru dalam menyusun administrasi mengajar dengan lengkap dan perencanaan mengajar melalui supervisi akademik sehingga menghasilkan pembelajaran yang lebih bermutu. Guru menunjukkan keseriusan dalam memahami dan menyusun administrasi mengajar apalagi setelah mendapatkan bimbingan pengembangan administrasi mengajar/ RPP dari peneliti sehingga terjadinya peningkatan, (2) Kegiatan supervisi akademik dapat meningkatkan kompetensi guru dalam menyiapkan perencanaan pembelajaran yang pada akhirnya meningkatkan mutu pembelajaran. Hal itu dapat dibuktikan dari hasil observasi /pengamatan yang memperlihatkan bahwa terjadi peningkatan kompetensi guru dalam mengajar dari siklus ke siklus sehingga terjadinya peningkatan dalam perencanaan pembelajaran.

Berdasarkan kesimpulan tersebut penulis dapat memberikan saran kepada pembaca khususnya dan kepala sekolah yang lain pada umumnya, antara lain: (1) Telah terbukti bahwa dengan bimbingan berkelanjutan dapat meningkatkan motivasi dan kompetensi guru dalam menyusun administrasi mengajar dan perencanaan pembelajaran. Oleh karena itu, peneliti 
menyampaikan beberapa saran sebagai berikut, (2) Motivasi yang sudah tertanam khususnya dalam penyusunan administrasi mengajar dan perencanaan pembelajaran hendaknya terus dipertahankan dan ditingkatkan, (3) Dokumen perencanaan pembelajaran hendaknya dibuat minimal 2 rangkap, satu untuk arsip sekolah dan satunya lagi untuk pegangan guru dalam melaksanakan proses pembelajaran.

\section{DAFTAR PUSTAKA}

Iim Waliman, dkk. 2001. Supervisi Kelas (Modul Manajemen Berbasis Sekolah). Bandung : Dinas

S Syaodih Nana, 2006. Pengendalian Mutu Pendidikan Sekolah Menengah (Konsep,prinsif, dan instrumen). Bandung : Aditama.

Undang-undang Republik Indonesia Nomor 20 Tahun 2003 tentang Sistem Pendidikan Nasional.

Peraturan Pemerintah Nomor 19 tahun 2005 tentang Standar Nasional Pendidikan.

Peraturan Pemerintah Nomor 22 tahun 2006 tentang Standar Isi untuk Satuan Pendidikan Dasar dan Menengah.

Piet, A. Sahertian. Frans Mataheru, 2001. Prinsip Teknik Supervisi Pendidikan, Surabaya, Usaha Nasional 